tion awards 126 will be attempted in the federal courts and that the older common law view barring resubmission of disputes will not be followed.127

\title{
CONCLUSION
}

The number of cases decided under section 301 is still too few to permit the statement of broad principles of the emerging law. Because the cases arise in factual contexts where the determinative considerations may differ for superficially similar cases, 128 the effect of precedent will not be strong for some time yet. Moreover, internal disagreements remain unsolved. Lower federal courts have reached divergent results, suggesting conflicting judicial attitudes toward enforcement of collective bargaining agreements under section 301.129 The Supreme Court remains itself divided: one camp espouses the development of a specialized industrial contract law; 130 the other places greater emphasis upon conventional contract doctrines. 131 The resolution of this conflict and its impact upon the development of substantive law under section 301 stimulates a continuing interest in litigation under this section.

126 American Brake Shoe Co. v. Local 149, UAW, 285 F.2d 869 (4th Cir. 1961); Howard v. United States Rubber Co., 190 F. Supp. 663 (D. Mass. 1961).

127 Enterprise Wheel \& Car Corp. v. United Steelworkers, 269 F.2d 327 (4th Cir. 1959), aff'd, 363 U.S. 593 (1960); Glendale Mfg. Co. v. Local 520, Garment Workers Union, 283 F.2d 936 (4th Cir. 1960). Contra, Mercury Oil Ref. Co. v. Oil Workers Union, 187 F.2d 980 (10th Cir. 1951).

${ }^{128}$ See, e.g., the discussion of the Patterson Parchment and Dahlem cases in the text at note 84 supra.

${ }^{129}$ See the discussion in text of the diversity of opinion in the lower federal courts concerning such questions as the application of the Westinghouse doctrine, the availability of declaratory relief under 301, and the arbitrability of breaches of no-strike clauses.

${ }^{130}$ See, e.g., Justice Douglas' remarks in Lewis v. Benedict Coal Corp., 361 U.S. 459, 468 (1959), and his statement in United Steelworkers v. Warrior \& Gulf Nav. Co., 363 U.S. 574 (1960), that "The agreement calls into being a new common law-the common law of a particular industry or of a particular plant." Id. at 579 . The view that the collective agreement is sui generis is criticized in Meltzer, supra note 121, at 480 \& n.68.

131 See, e.g., Justice Whittaker's dissent in the Warrior case, supra note 130, at 585, and Justice Frankfurter's dissenting opinion in Benedict, supra note 130. The apparent division on the Court is reviewed in terms of the recent arbitration cases in Gould, The Supreme Court and Labor Arbitration, 12 LAB. L. J. 331 (1961).

\section{LEX LOCI DELICTI OR LEX FORI?-CONFLICT OF LAWS IN WRONGFUL DEATH ACTIONS AND THE KILBERG CASE}

"Few principles of conflict of laws are as well settled as that, in an action to recover for wrongful death, it is the lex loci delicti which is controlling." 1 The law of the place of injury has been almost uniformly held to determine the

1 Annot., Death of Passenger-Law Applicable, 13 A.L.R.2d 650 (1950). See RestateMENT, CONFICT OF LAWS $\S 391-95$ (1934); 11 AM. JUR. Conflict of Laws § 182 (1937); 2 Beale, Conflict of Laws $\$ 391$ (1935); Goodrich, Conflict of Laws $\$ 102$ (3d ed. 1949). 
right to sue for wrongful death, 2 the proper person to bring the action, 3 the persons entitled to share in the recovery, 4 the period within which the action can be brought, 5 and the amount of damages recoverable. 6 The rule is predicated on the doctrine of "vested rights," i.e., that the tortious act immediately gives rise to an obligation on the tortfeasor according to the then exist-

2 E.g., Northern Pac. R.R. v. Babcock, 154 U.S. 190 (1894); Faron v. Eastern Airlines, Inc., 193 Misc. 395, 84 N.Y.S.2d 568 (1948); Louisville \& N.R.R. v. Williams, 113 Ala. 402, 21 So. 938 (1897). See Restatement, Conflict of Laws $\$ 391$ (1934). Note especially $\S 391$ (c): "The statute of the forum does not create a right of action for death if the injury to the decedent was inflicted elsewhere." Contra, Beach v. Bay State Co., 27 Barb. 248 (N.Y. 1858), where the court held that the New York wrongful death act was applicable whether or not the injury causing the death occurred in New York.

3 E.g., Rybolt v. Jarrett, 112 F.2d 642 (4th Cir. 1940); Ghilain v. Couture, 84 N.H. 48, 146 Atl. 395 (1929); Weiner v. Specific Pharmaceuticals, Inc., 298 N.Y. 346, 83 N.E.2d 673 (1949). See Restatement, Conflict of Laws $\S \S 394-95$ (1934). But see Howard v. Pulver, 329 Mich. 415, 45 N.W.2d 530 (1951), where the court apparently applied the law of the forum to determine that plaintiff was the proper "personal representative" and, therefore, entitled to bring the action.

"The question of the proper person to sue upon a foreign based death by wrongful act claim has been a fruitful source of litigation. Owing to the usual short period of limitation in this type of case the selection of the wrong person to sue may make recovery impossible." Cheatham, GOODRICH, Griswold \& ReESe, CASES ON CONFLict of LAWs 454 (4th ed. 1957). See Annot., 65 A.L.R. 563 (1930); Note, 54 Mich. L. ReV. 821 (1956).

4 E.g., In re Gutkowski's Estate, 135 N.J. Eq. 93, 33 A.2d 361 (1943); In re Petrasek's Estate, 191 Misc. 9, 79 N.Y.S.2d 561 (1948); Free v. Southern Ry., 78 S.C. 57, 58 S.E. 952 (1907). See Restatement, Conflict OF LAWS $\$ 393$ (1934).

5 E.g., Engel v. Davenport, 271 U.S. 33 (1926); Cristilly v. Warner, 87 Conn. 461, 88 Atl. 711 (1913); Negaubauer v. Great No. Ry., 92 Minn. 184, 99 N.W. 620 (1904). "A recovery under a death statute of the place of wrong cannot be had in any state after the time fixed in the statute for bringing an action has elapsed." RESTATEMENT, CONFLICT OF LAwS $§ 397$ (1934).

But see Wells v. Simonds Abrasive Co., 345 U.S. 514 (1953), where the Court held that the Pennsylvania court did not violate the full faith and credit clause in applying its own statute of limitations rather than that of the place of injury. See also Tieffenbrun v. Flannery, 198 N.C. 397, 151 S.E. 857 (1930), and cases collected in Annot., 68 A.L.R. 217 (1930) and 146 A.L.R. 1356 (1943).

6 E.g., Frasier v. Public Serv. Interstate Transp. Co., 254 F.2d 132 (2d Cir. 1958); Stoltz v. Burlington Transp. Co., 178 F.2d 514 (10th Cir. 1949), cert. denied, 339 U.S. 929 (1950); Curtis v. Campbell, 76 F.2d 84 (3d Cir.), cert. denied, 295 U.S. 737 (1935); Barnes v. Union Pac. R.R., 139 F. Supp. 198 (S.D. Idaho 1956); Gould v. Boston \& M.R.R., 282 Mass. 160, 184 N.E. 449 (1933). See Restatement, CONFIICT OF LAWs $\$ \$ 391(d), 417$ (1934), and cases collected in 15 A.L.R.2d 762 (1951).

Contra, Armbruster v. Chicago R.I. \& P. Ry., 166 Iowa 155, 147 N.W. 337 (1914); Rochester v. Wells, Fargo \& Co. Express, 87 Kan. 164, 123 Pac. 729 (1912); Higgins v. Central N.E. \& W.R.R., 155 Mass. 176, 29 N.E. 534 (1892). In these cases the forum maintained a limitation on the amount of damages while the lex loci delicti had no such limitation. In applying the law of the forum, the courts rested their holdings on the rationale that plaintiff had waived his right to extended damages under the lex loci delicti by bringing his action in a state restricting recovery.

See also Wooden v. Western N.Y. \& P.R.R., 126 N.Y. 10, 26 N.E. 1050 (1891), supporting the Restatement's position that the forum will always enforce its own limitation on the amount of recovery. Restatement, CONFLICT of LAWs $\$ 417$, comment $a$ (1934). More recent decisions have rejected this rule: Stoltz v. Burlington Transp. Co., supra; Zirkelbach v. Decatur Cartage Co., 119 F. Supp. 753 (N.D. Ind. 1954). 
ing law of the place where the tort occurred. ${ }^{7}$ Because the action against the wrongdoer is transitory in nature, this obligation may be enforced against him wherever he is found.8

Notable resistance to the rule is found, however, in cases where the death statute of the place of injury contains a limitation on the amount recoverable, while the forum's statute does not, and the deceased is a domiciliary of the forum state. 9 To escape from the operation of the lex loci delicti rule in this situation three counterbalancing conflict of laws rules have been advanced with limited success: (1) that the issue of damages should be characterized as procedural, thereby applying the law of the forum, (2) that the court should refuse to apply the limited damage provision of the place of injury's statute on the ground that it is contrary to the public policy of the forum, and thus substitute the lex fori, and (3) in cases where the death has occurred while the deceased was a passenger on a common carrier, that the death action should be characterized as a contract action for breach of an implied promise of safe carriage, thereby applying the law of the place of contracting. In Kilberg $v$. Northeast Airlines, Inc., 10 the New York Court of Appeals considered all three of these theories in an effort to find a doctrinal basis whereby the consequences of the lex loci delicti rule could be avoided.

In Kilberg the deceased, a resident and citizen of New York, had purchased in New York a ticket for a flight on defendant's airline from New York to Massachusetts. The deceased was fatally injured when the plane in which he was a passenger crashed in Massachusetts. At the time of the accident the Massachusett's wrongful death statute prescribed a limitation of $\$ 15,000$ damages as against common carriers; 11 New York maintains no such limitation.12

7 See Loucks v. Standard Oil Co., 224 N.Y. 99, 120 N.E. 198 (1918) (Cardozo, J.). Mr. Justice Holmes was a leading exponent of the "vested rights" theory: "The theory of the foreign suit is that although the act complained of was subject to no law having force in the forum, it gave rise to an obligation, an obligatio, which, like other obligations, follows the person, and may be enforced wherever the person may be found." Slater v. Mexican Nat"l R.R., 194 U.S. 120, 126 (1904).

8 See Beach, Uniform Interstate Enforcement of Vested Rights, 27 YALE L.J. 656 (1918); Currie, The Constitution and the "Transitory" Cause of Action, 73 HARv. L. Rev. 36, 66-82 (1959).

9 Maynard v. Eastern Air Lines, Inc., 178 F.2d 139 (2d Cir. 1949); Curtis v. Campbell, 76 F.2d 84 (3d Cir.), cert. denied, 295 U.S. 737 (1935); Kilberg v. Northeast Airlines, Inc., 9 N.Y.2d 34, 172 N.E.2d 526, 211 N.Y.S.2d 133 (1961). A similar problem is presented where the state of injury allows unlimited recovery but the forum maintains a limitation on the amount of damages, and the defendant is a domiciliary of the forum state. See Wooden v. Western N.Y. \& P.R.R., 126 N.Y. 10, 26 N.E. 1050 (1891).

109 N.Y.2d 34, 172 N.E.2d 526, 211 N.Y.S.2d 133 (1961).

11 Mass ANN. Laws ch. 229, §2 (1955). The limitation has now been extended to $\$ 20,000$. Mass. ANN. LAws ch. 229, $\S 2$ (Supp. 1960). Some thirteen states also maintain limitations on the amount recoverable in death actions. E.g., Colo. Rev. STAt. AnN. \& 41-1-1 (1953); ILl. Rev. Stat. ch. 70, § 2 (1959); ME. Rev. Stat. ANN. ch. 165, § 10 (1954).

12 N.Y. Deced. EsT. LAW § 132. 
Although plaintiff-administrator's first cause of action asserted recovery under the Massachusett's statute, his second cause alleged that the defendant carrier "breached its contract to carry him [deceased] safely and that as a result the passenger's estate and his dependent suffered substantial damages (stated as $\$ 150,000)$. . . which include 'loss of accumulations of prospective earnings.' ..."13 The contract for passage having been made in New York, the remedy for its breach should be governed by New York law.14 As in previous cases, 15 the court rejected this theory.

The reluctance of the court to characterize the action as one of contract rather than of tort is probably the result of the peculiar statutory nature of the death action. At common law no action for damages could be maintained against a party for the wrongful killing of another. 16 The right to sue for death is created and regulated solely by statute.17 To allow a contract action for death damages would create an action prohibited by common law and not specifically authorized by statute. This explanation seems particularly likely in view of the fact that the New York court has readily indulged in contract characterization to circumvent a sister state's damage limitation in cases

139 N.Y.2d at -, 172 N.E.2d at 527, 211 N.Y.S.2d at 134.

14 Fish v. Delaware L. \& W.R.R., 211 N.Y. 374, 105 N.E. 661 (1914); Dyke v. Erie Ry., 45 N.Y. 113, 6 Am. Rep. 43 (1871).

15 Baldwin v. Powell, 294 N.Y. 130, 61 N.E.2d 412 (1945); Whitford v. Panama R.R., 23 N.Y. 465 (1861). In Maynard v. Eastern Air Lines, Inc., 178 F.2d 139 (2d Cir. 1949), plaintiff's husband purchased a ticket in New York for passage on defendant's aircraft to Massachusetts. He was killed as a result of a crash in Connecticut which maintained a limit of $\$ 20,000$ on death damages. Plaintiff brought an action in a New York district court to recover $\$ 250,000$ in damages for the death, alleging that the action was simply one in contract for breach of an implied promise of safe carriage, and that, the contract having been entered into in New York, that state's law was applicable. Although sympathetic with plaintiff's position, the court concluded that "where, as here, the gravamen of the cause of action is an alleged breach of a duty through negligence, the action is governed by the applicable law of torts, even though the allegations refer to a breach of contract." $178 \mathrm{~F} .2 \mathrm{~d}$ at $140-41$, quoting from Faron v. Eastern Airlines, Inc., 193 Misc. 395, 397, 84 N.Y.S.2d 568, 570 (1948).

16 The common law rule was established by Lord Ellenborough in Baker v. Bolton, 1 Camp. 493, 170 Eng. Rep. 1033 (1808). See 3 HoldswORTH, History OF ENGLISH LAW 33336, 576-85, 676-77 (3d ed. 1922); POLIOCK, LAW OF TORTs 66-72 (12th ed. 1923); Prosser, TORTS 705-10 (2d ed. 1955); TIFFANY, DeATH BY WRONGFul ACT (2d ed. 1913); Comment, Survival and Wrongful Death Actions $-A$ Confusion of Common Law Origins and the Present Status of the Law, 35 U. DET. L.J. 72 (1957).

17 ' $[\mathrm{m}$ t is law long settled that wrongful death actions, being unknown to the common law, derive from statutes only and that the statute which governs such an action is that of the place of the wrong. ... It follows ... that plaintiff as administrator has no separate right to sue this carrier in contract for causing his intestate's death. ..." 9 N.Y.2d at -, 172 N.E.2d at 527, 211 N.Y.S.2d at 135.

The American statutes have generally followed Lord Campbell's Act, 9 \& 10 Vict. c. 93 (1846). These statutes are collected in Rose, Foreign Enforcements of Actions for Wrongful Death, 33 MrCH. L. Rev. 545, 587-96 (1935). Recent amendments can be found in 4 MARTINDALE-HubBeIL LAW Digest (1960 ed.). 
where the action is one for personal injuries, an action recognized at common law. 18

Although endorsing the lex loci delicti rule and holding that Kilberg's right of action for wrongful death was governed by the Massachusetts statute, the court, on its own motion, held that recovery was not restricted to the Massachusetts limitation. 19 The court appears to have placed this latter holding on alternative grounds-that New York public policy prohibited the enforcement of the limitation, and that the question of damages was procedural, rather than substantive, in nature. Both grounds called for the application of the law of the forum.

The court found that "New York's public policy prohibiting the imposition of limits on such damages is strong, clear and old." 20 Because the New York Constitution expressly states that "the amount recoverable shall not be subject to any statutory limitation," 21 the court concluded that "for our courts to be limited by this damage ceiling (at least as to our own domiciliaries) is so completely contrary to our public policy that we should refuse to apply that part of the Massachusetts law...."22

This holding appears to contravene the widely praised case of Loucks $v$. Standard Oil Co., ${ }^{23}$ which also involved a wrongful death action in which a New York decedent had been killed in Massachusetts. At the time of the death a Massachusetts statute, similar to the one involved in Kilberg, limited recovery and measured the amount of damages according to the culpability of the defendant. Writing for the court, Judge Cardozo con-

18 In Dyke v. Erie Ry., 45 N.Y. 113, 6 Am. Rep. 43 (1871), plaintiff, a New York domiciliary, purchased a ticket in New York for passage on defendant's railroad. On the trip to New York City he was injured as the train was passing through Pennsylvania. The Pennsylvania statute limited liability of common carriers to $\$ 3,000$, but the forum had no limitation. In holding that the action in contract for breach of an implied promise of safe passage was properly brought, the New York court used this interesting language:

"Whatever was done in Pennsylvania was a part of the single act of transportation ... and in performance of an obligation assumed and undertaken in this State, and which was indivisible. The obligation was created here, and by force of the laws of this State, and force and effect must be given to it, in conformity to the laws of New York. . . Effect will not be given by the courts of a State to foreign laws in derogation of the contracts, or prejudicial to the rights of citizens. ... The actions are not given by the laws of Pennsylvania. They grow out of the contracts and the duties resulting from the contracts, and are given by the common law, and, therefore, the law of another State in an action brought here cannot prescribe the measure of damages, or limit the liability of the parties." 45 N.Y. at 117-19. (Emphasis added.)

19 While the court unanimously agreed that the contract action should be struck down, a minority of three maintained that the Massachusetts limit should be controlling. 9 N.Y.2d at -, 172 N.E.2d at $529-35,211$ N.Y.S.2d at 138-46.

209 N.Y.2d at -, 172 N.E.2d at 528, 211 N.Y.S.2d at 136.

21 N.Y.CONST, art. I, §16.

229 N.Y.2d at -, 172 N.E.2d at 528, 211 N.Y.S.2d at 136.

23224 N.Y. 99, 120 N.E. 198 (1918) (Cardozo, J.). 
cluded that there was "nothing in the Massachusetts statute that outrages the public policy of New York."'24

The two cases point out the two different ways in which "local public policy" has been utilized in the conflict of laws. In Loucks the question presented to the court was whether New York would entertain an action predicated on a foreign statute which was allegedly contrary to the law of the forum. In Kilberg the question was whether New York would recognize and enforce a defense based on a foreign statute which was contrary to the law of the forum. Use of public policy in the first way, since it leads only to a dismissal of the action, presumably does not adjudicate the merits of the case or the rights of the parties, 25 while the second does.26 Although resort to the public policy concept to dismiss an action based on foreign law has been frowned upon, 27 it remains an acceptable conflict of laws technique. 28 The use

$24 \mathrm{Id}$. at 111,120 N.E. at 202. The question before the court in Loucks was whether New York would apply the Massachusetts statute at all. The opinion is considered an enlightened one in that it rejects the "dissimilarity" doctrine, whereby one state will not apply the law of another if the two are not substantially similar. (The New York death statute is purely compensatory, while that of Massachusetts is both compensatory and penal. See Notes, 27 B.U.L. REv. 88 (1947); 29 B.U.L. REv. 523 (1949).) Judge Cardozo saw the question simply as whether to apply the Massachusetts law or dismiss the action. He had no doubt that only Massachusetts law was applicable:

"Through the defendant's negligence, a resident of New York has been killed in Massachusetts. He has left a widow and children who are also residents. The law of Massachusetts gives them a recompense for his death. It cannot be that public policy forbids our courts to help in collecting what belongs to them. We cannot give them the same judgment that our law would give if the wrong had been done here. Very likely we cannot give them as much. But that is no reason for refusing to give them what we can." Id. at 111-12, 120 N.E. at 202. (Emphasis added.)

It is suggested that an even more enlightened approach would have extended the benefit of New York law to the New York parties. Furthermore, it has been suggested that a refusal to extend the benefit of the forum's law to a domiciliary on the basis of the occurrence of the wrong is a denial of equal protection of the law. See Currie \& Schreter, Unconstitutional Discrimination in the Conflict of Laws: Equal Protection, 28 U. CHI. L. Rev. 1, 47 (1960). See note 67 infra.

25 Mertz v. Mertz, 271 N.Y. 466, 3 N.E.2d 597 (1936); Loucks v. Standard Oil Co., 224 N.Y. 99, 120 N.E. 198 (1918).

26 Fox v. Postal Tel.-Cable Co., 138 Wis. 648, 120 N.W. 399 (1909).

27 "In the interstate field there is considerable authority to support the view that there is, or should be, no place for the use of the public policy argument." Nussbaum, Public Policy and the Political Crisis in the Conflict of Laws, 49 YALE L. J. 1027, 1052-53 (1940). See also Beach, Uniform Interstate Enforcement of Vested Rights, 27 YALE L. J. 656 (1918); Goodrich, Foreign Facts and Local Fancies, 25 VA. L. Rev. 26 (1938); Lorenzen, Territoriality, Public Policy and the Conflict of Laws, 33 YALE L. J. 736 (1924); Nutting, Suggested Limitations of the Public Policy Doctrine, 19 MINN. L. REv. 196 (1935).

28 This statement may be challenged in view of Hughes v. Fetter, 341 U.S. 609 (1951) and First Nat'I Bank v. United Air Lines, Inc., 342 U.S. 396 (1952), which held that it was a denial of full faith and credit for a court to refuse to entertain wrongful death actions on the basis that local public policy, as expressed in statutes, prohibited the bringing of such actions when the fatal injury occurred outside the forum state. The Supreme Court, however, found that the forum statutes did not express a justifiable or legitimate public policy, for the forum states had "no real feeling of antagonism against wrongful death suits in general." 341 U.S. at 612. The Court in Hughes goes so far as to suggest that if the statute could be 
of public policy to deny a defense recognized under the foreign law has also been widely criticized 29 and has even been held to be unconstitutional as a denial of full faith and credit to the foreign law:30

A State may, on occasion, decline to enforce a foreign cause of action. In so doing, it merely denies a remedy, leaving unimpaired the plaintiff's substantive right, so that he is free to enforce it elsewhere. But to refuse to give effect to a substantive defense under the applicable law of another State, as under the circumstances here presented, subjects the defendant to irremediable liability. This may not be done. ${ }^{31}$

The distinction is an appealing one, but it is suggested that it is a distinction without merit. Practically speaking, the dismissal of an action or denial of a remedy may effectively adjudicate the case where there is only one forum in which the plaintiff may bring the action. ${ }^{32}$ Furthermore, it cannot be assumed that when a state denies relief to a plaintiff on the ground of public policy, he may still enforce his claim in another jurisdiction. It is often difficult to determine whether the denial of relief is a dismissal only or a judgment "on the merits." 33 If a court in the second jurisdiction construes the first judgment as one "on the merits," the plaintiff may be effectively denied relief. ${ }^{34}$ In an analytical context, to refuse to enforce a defense of the foreign law is simply to apply the law of the forum. Therefore, it is unconstitutional to deny the foreign defense only if it is unconstitutional to apply the lex fori. Whether a court chooses to say that local public policy prohibits the application of a foreign law or that local public policy requires the application of the law of the forum should make no difference when determining whether non-application of the foreign law is a denial of full faith and credit to that law. Thus, if the New York court was constitutionally justified in applying its own law in Kilberg, it should likewise be justified in denying recognition of the foreign (Massachusetts) law. 35

construed as an expression of the forum non conveniens doctrine, it would express a legitimate policy of the forum, and thus the forum would not be compelled to entertain the suit.

${ }^{29}$ Paulsen \& Sovern, "Public Policy" in the Conflict of Laws, 56 CoLum. L. Rev. 969, 979-80, 1016 (1956). See also articles cited note 27 supra.

30 Bradford Elec. Light Co. v. Clapper, 286 U.S. 145 (1932).

$31 \mathrm{Id}$. at 160.

32 Service of process on the defendant may only be possible in one jurisdiction. $C f$. Ciampittiello v. Campitello, 134 Conn. 51, 54 A.2d 669 (1947); Kentucky Fin. Corp. v. Paramount Auto Exch. Corp., 262 U.S. 544, 549-50 (1923).

33 See Angel v. Bullington, 330 U.S. 183 (1947); Union Trust Co. v. Grosman, 228 Fed. 610 (5th Cir. 1916), aff'd, 245 U.S. 412 (1918).

34 "[n] the plaintiff files suit in a second forum, and the defendant pleads a prior judgment in his favor which purports to be on the merits, established doctrine precludes the plaintiff from attacking that judgment on the ground that it constitutes a denial of full faith and credit; his only recourse is to seek direct review of the first judgment." Currie, The Constitution and the Choice of Law: Governmental Interests and the Judicial Function, $26 \mathrm{U}$. CHr. L. REv. 9, 29 n.87 (1958), citing Treinies v. Sunshine Mining Co., 308 U.S. 66 (1939).

35 The question is considered in part III infra. 
In addition to the public policy holding, the court in Kilberg further held that the question of damages in wrongful death actions is one of procedure, and is thus governed by the law of the forum. This conclusion flies in the face of the Restatement, 36 the treatise writers, 37 and the great majority of courts which have considered the question. ${ }^{38}$ All these authorities conclude that the issue of damages in wrongful death actions is substantive in nature and, therefore, governed by the law of the place of the injury. Having recognized that an action for wrongful death is created only by statute and has no counterpart in the common law, 39 the court appears to have been highly inconsistent in holding that the right of action can be separated from the remedy provided by the statute. Surely the damage provision of a wrongful death statute is an integral part of the action created, and thus is properly characterized as a substantive provision. The procedural characterization appears to be simply a device to place the opinion on a less controversial legal ground than that of public policy. 40

36 "The law of the place of wrong governs the amount of recovery for wrongful death as well as the right to recover. Thus, any limitation upon the amount imposed by the law of the place of wrong will be applicable to determine the maximum amount recoverable elsewhere. ..." RESTATEMENT, CONFLICT OF LAWS § 391(d) (1934).

37 See generally 2 Beale, Conflict of LaWs 1305-16 (1935); CoOK, The Logical aND LEGAL BASIS OF THE CONFLICT OF LAWS 311-46 (1949); GOODRICH, CONFLICT OF LAWS § 105 (3d ed. 1949); LEFLAR, CONFLICT OF LAWS $\$ 114$ (1959); 2 WHARTON, CONFLICT OF LAWS 1108-13 (3d ed. 1905).

${ }^{38}$ See cases cited note 6 supra.

${ }^{39}$ See text at notes 15-17 supra.

40 "Our courts should if possible provide protection for our own State's people against unfair and anachronistic treatment of the lawsuits which result from these disasters. There is available, we find, a way of accomplishing this conformably to our State's public policy and without doing violence to the accepted pattern of conflict of law rules." 9 N.Y.2d at -, 172 N.E.2d at 527-28, 211 N.Y.S.2d at 135.

See Walsh v. Boston \& M.R.R., 201 Mass. 527, 88 N.E. 12 (1909); Herrick v. Minnesota \& St. L. Ry., 31 Minn. 11, 16 N.W. 413 (1883); Wooden v. Western N.Y. \& P.R.R., 126 N.Y. 10, 26 N.E. 1050 (1891), all holding the issue of damages to be procedural. The Wooden case was decided when New York maintained a statutory limit on the amount of damages recoverable. The deceased and his beneficiaries were domiciliaries of New York, and the defendant was a New York corporation. The death had occurred in Pennsylvania. The court stated: "the restriction indicates our public policy as to the extent of the remedy, and the plaintiff who chooses to avail herself of our remedial procedure must submit to our remedial limitations and be content with a judgment beyond which our courts cannot go." 126 N.Y. at 17,26 N.E. at 1051.

A related attack on the lex loci delicti rule is suggested by construing the forum's death statute as simply removing a procedural defect of the common law rule prohibiting wrongful death actions, i.e., the absence of a party to bring the action (the injured party being deceased). Thus, the death statute may be treated as procedural in nature, and the forum is free to apply its own procedural law. $C f$. Grant v. McAuliffe, 41 Cal. 2d 859, 264 P.2d 944 (1953). This is particularly persuasive if the forum's statute is of the "survival" type, rather than one which creates a new cause of action for specified beneficiaries. See PROSSER, TORTS 705-09 (2d ed. 1955). Stewart v. Baltimore \& O.R.R., 168 U.S. 445 (1897), intimates that a death statute may be so construed. 


\section{II}

The result in Kilberg may be praised by those who urge greater recovery for plaintiffs in actions for wrongful death. 41 But was the result a proper one? New York has clearly expressed its policy of allowing unlimited recovery in death actions. This determination undoubtedly was made for the protection of its own domiciliaries. ${ }^{42}$ The deceased and beneficiaries were domiciliaries of New York. Defendant, by doing business in New York, must be assumed to be aware of this policy and to conduct his conduct and business in reference to this policy. ${ }^{43}$ On the other hand, the Massachusetts statute expresses a policy of protecting defendants from excessive damages. Again, this protection is directed toward its own citizens and residents. In Kilberg, the defendant was a corporation chartered under the laws of Massachusetts. There is a true conflict in this case: New York's policy would be advanced by applying its law to benefit the plaintiff; 44 Massachusett's policy would be promoted by having its law applied to protect the defendant. Does the place-of-injury rule in this situation provide a reasonable and rational means to resolve this conflict? To this question the New York court answered:

Modern conditions make it unjust and anomalous to subject the traveling citizen of this State to the varying laws of other States through and over which they move. ... An air traveler from New York may in a flight of a few hours' duration pass through several ... commonwealths. His plane may meet with disaster in a State he never intended to cross but into which the plane has flown because of bad

41 See N.A.C.C.A. News Letter (Vol. 4 no. 2), Feb. 1961, p. 2.

42 Death statutes may be interpreted as providing protection to either the deceased or his designated beneficiaries (usually next-of-kin). It is protection to the decedent in the sense that it may be compared to an insurance policy protecting him from accidental death. It is protection to the beneficiaries in that they are made the designated recipients of the damage award. When both the deceased and beneficiaries are forum domiciliaries it is unnecessary to choose between the interpretations. When the deceased is a domiciliary but the beneficiaries are non-residents, the choice of interpretation becomes essential in order to determine whether the forum has an interest in extending the benefit of its law. Professor Currie suggests that the forum should look to the domicile or residence of the deceased: "The resident himself benefits from this assurance; it is valuable to him in the same way that a contract of accident insurance payable to his dependents would be." Currie, The Constitution and the "Transitory" Cause of Action, 73 HARv. L. Rev. 36, 47 (1959). See also Currie, Survival of Actions: Adjudication versus Automation in the Conflict of Laws, 10 STAN. L. REv. 205, 221-22 (1958). This interpretation is contradicted by Chambers v. Baltimore \& O.R.R., 207 U.S. 142 (1907), in which the Court held that for purposes of the privileges and immunities clause, it would look to the beneficiary, or the plaintiff (it is not clear which) as the object of the Constitution's protection. In his dissent Mr. Justice Harlan urged the Court to focus its attention on the deceased. 207 U.S. at 157-60.

${ }^{43}$ It has been pointed out that it is actually the defendant's insurance company which must bear the increased damage judgment in most cases. Note, 49 CALIF. L. REv. 187, 191-93 (1961). This does not affect the suggested analysis; the insurer must be presumed to insure with reference to defendant doing business in New York.

44 The plaintiff-administrator is actually only a nominal party designated by statute to bring the suit. The real parties in interest are the beneficiaries or the deceased. See note 42 supra. 
weather or other unexpected developments, or an airplane's catastrophic descent may begin in one State and end in another. The place of injury becomes entirely fortuitous. 45

It seems clear that accepted choice of law doctrine does not provide an adequate means to resolve the conflict in this situation. 46 Any rule which would require the forum state to defer to the law of another state and thus defeat its own legitimate interest in the case seems undesirable-and even absurd.47

The result in Kilberg may be a desirable one, but the theories upon which the court rested its decision do not provide any more rational solution to the conflict of interests problem than the lex loci delicti rule. Having determined that New York policy prohibits the imposition of a limit on the amount recoverable by the New York plaintiff, it seems unnecessary for the court to hold that the damage issue is procedural. By doing so, it thereby has announced a rule which is applicable to the question of damages in every wrongful death situation. Surely the policy of the New York statute would not be advanced by application of its damage provision when the action is one for the death of a Massachusetts domiciliary whose beneficiaries are also Massachusetts domiciliaries. The procedural holding, however, would require such a result. 48

Even if the court had decided the case on public policy grounds alone, this holding would not be free from ambiguity. Is the court saying that its public policy prohibits the application of a damage limitation when the decedent and his beneficiaries are New York domiciliaries, or is it perhaps asserting a more inclusive rule to the effect that damage limitations cannot be enforced in New York courts in any situation? Certain language in the opinion suggests the

459 N.Y.2d at -, 172 N.E.2d at 527, 211 N.Y.S.2d at 135. See also Pearson v. Northeast Airlines, Inc., 180 F. Supp. 97, 98-99 (S.D.N.Y. 1960): "In the light of the extensive and common use of the airplane in modern times with most flights traversing state after state beyond the point of origin, the vagaries of differing wrongful death acts coming into play in the event of an accident may make it desirable that earlier doctrines [of conflict of laws] be reconsidered."

46 "When each of two states related to a case has a legitimate interest in the application of its law and policy, a problem is presented which cannot be rationally solved by any method of conflict of laws-that is to say, by any effort, legislative or judicial, on the part of the states concerned to establish universal choice-of-law rules. In such a context, a choice-oflaw rule is simply a device which, typically without explicitly saying so, subordinates the interest of one state to that of the other. A court is ordinarily not warranted in sacrificing interests of its own state for the sake of interstate uniformity of result." Currie, The Constitution and the Choice of Law: Governmental Interests and the Judicial Function, 26 U. CHI. L. Rev. 9, 10 (1958). Constitutional doctrines may, however, prescribe the proper law. See part III infra.

47 "If . . the forum state has an interest in the application of its law and policy, it should apply the law of the forum even though the foreign state also has such an interest...." Currie, supra note 46, at 10.

48 See text infra at notes 70-72. 
former, 49 but the holding is framed in terms of the latter. 50 To construe the holding as enunciating the more inclusive holding would require the court to apply the unrestricted damage provision in a case in which New York has no legitimate interest, i.e., a case in which New York would not advance its policy of protecting its domiciliaries by applying its unlimited damage provision. 51

\section{III}

The above discussion has assumed that the New York court is constitutionally free to apply whichever law it chooses to adjudicate the administrator's claim. It may be, however, that the forum is precluded from applying its own law and is required under the full faith and credit clause of the federal constitution to apply the law of Massachusetts, the place of injury. In his concurring opinion in Kilberg,52 Judge Froessel expressed "grave doubts" as to the constitutionality of the majority's application of the lex fori in view of the Supreme Court's decision in Hughes v. Fetter. ${ }^{53}$ In that case a domiciliary of Wisconsin was killed in an automobile accident in Illinois. His administrator, basing an action on the Illinois wrongful death statute, sued the driver of the other car and his insurance company in a Wisconsin state court. The defendant driver was also a domiciliary of Wisconsin, and the insurance company was a corporation chartered under Wisconsin law. On the defendants' motion, the trial court dismissed the complaint "on the merits." The Wisconsin Supreme Court affirmed the dismissal, on the ground that a Wisconsin statute which created an action for wrongful death only if the death occurred within Wisconsin, established a "public policy against Wisconsin's entertaining suits brought under the wrongful death acts of other states." 54 The United States Supreme Court reversed the Wisconsin decision, holding that this interpretation of the statute violated the full faith and credit clause of the Constitution, and that the Wisconsin courts were required to entertain the action. The Court found that the case presented a conflict between "the strong unifying principle embodied in the Full Faith and Credit Clause looking toward maximum enforcement in each state of the obligations or rights created or recognized by

49 "Our courts should if possible provide protection for our own State's people against unfair and anachronistic treatment of the lawsuits which result from these disasters.... For our courts to be limited by this damage ceiling (at least as to our own domiciliaries) is so completely contrary to our public policy that we should refuse to apply that part of the Massachusetts law. . . ." 9 N.Y.2d at -, 172 N.E.2d at 527-28, 211 N.Y.S.2d at 135-36. (Emphasis added.)

50 "We will still require plaintiff to sue on the Massachusetts statute but we refuse on public policy grounds to enforce one of its provisions as to damages." 9 N.Y.2d at - 172 N.E.2d at 528,211 N.Y.S.2d at 136-37.

51 Such a situation is the one described in the preceding paragraph, where the decedent and his beneficiaries are not domiciliaries of the forum state.

529 N.Y.2d at -, 172 N.E.2d at 535, 211 N.Y.S.2d at 146.

53341 U.S. 609 (1951).

54 Id. at 610 . 
the statutes of sister states ... [and] the policy of Wisconsin, as interpreted by its highest court, against permitting Wisconsin courts to entertain this wrongful death action." 55 The Court concluded: "We hold that Wisconsin's policy [of not entertaining death actions where the death occurred outside the forum] must give way. That state has no real feeling of antagonism against wrongful death suits in general. To the contrary, a forum is regularly provided for cases of this nature...."s6

Does the Hughes decision require the forum to apply the lex loci delicti in a case such as Kilberg? Several considerations indicate that it does not. In Hughes the Wisconsin court had not attempted to adjudicate the case under its own law; it had simply denied the plaintiff the right to sue in Wisconsin. Indeed, the plaintiff had predicated his case solely on the Illinois statute. The Supreme Court recognized this distinction in a footnote to its opinion:

The present case in not one where Wisconsin, having entertained appellant's lawsuit, chose to apply its own instead of Illinois' statute to measure the substantive rights involved. This distinguishes the present case from those where we have said that "Prima facie every state is entitled to enforce in its own courts its own statutes, lawfully enacted." 57

The Court in this passage appears to have been saying: "Wisconsin must open its doors to this action even though the injury occurred in Illinois, but we do not consider what law is to be applied to adjudicate the merits of the case-in fact, Wisconsin may have an interest in this situation sufficient to justify the application of its own laws." Although such an interpretation of the case is

${ }^{55} \mathrm{Id}$. at 612 .

56 Ibid. A similar case is First Nat'1 Bank v. United Air Lines, Inc., 342 U.S. 396 (1952), in which an executor bank brought a wrongful death action for an airplane crash in Utah which caused the death of an Illinois citizen. The defendant airline was doing business in Illinois and the deceased's beneficiaries were Illinois domiciliaries. An Illinois statute prohibited the entertainment of a foreign death action when the state where the death occurred gave such an action and the defendant could be served with process therein. Because the airline was doing business in Utah, the Federal District Court of the Northern District of Illinois, relying on Erie R.R. v. Tompkins, 304 U.S. 64 (1938), dismissed the action. The Court of Appeals affirmed in a per curiam opinion. 190 F.2d 493 (7th Cir. 1951). On appeal, the Supreme Court held that the full faith and credit clause forbade the application of the Illinois statute, finding that the case was governed by Hughes.

"The Illinois statute before us today is the exact duplicate of the Wisconsin statute with the single exception that suit is permitted in Illinois under another state's wrongful death statute if service of process cannot be had on the defendant in the state where the death was brought about. That Illinois is willing for its courts to try some out-of-state death actions is no reason for its refusal to grant full faith and credit as to others. . . . Nor is it crucial here that Illinois only excludes cases that can be tried in other states. We hold again that the Full Faith and Credit Clause forbids such exclusion." 342 U.S. at 400 (Justices Jackson and Minton concurring in the result; Justices Reed and Frankfurter dissenting).

57341 U.S. at 612 n.10, citing Alaska Packers Ass'n v. Industrial Acc. Comm'n, 294 U.S. 532, 547 (1935). 
inconsistent with its full faith and credit language, 58 it is entirely consistent with other language in the opinion and previous and later Supreme Court decisions. 59 In Alaska Packers Ass'n v. Industrial Acc. Comm'n, 60 the Court stated that "one who challenges that right [the right of a state to enforce in its own courts its own statutes], because of the force given to a conflicting statute of another state by the full faith and credit clause, assumes the burden of showing, upon some rational basis, that of the conflicting interests involved those of the foreign state are superior to those of the forum."61 And in Carroll v. Lanza, ${ }^{62}$ Watson v. Employers Liab. Ins. Corp. ${ }^{63}$ and Pacific Employers Ins. Co. v. Industrial Acc. Comm'n, 64 the Court held that the forum state need have no more than a "legitimate interest" in the application of its own law to justify its use, not one which outweighs the interest of the foreign state.

Under these latter cases it would seem that Wisconsin would be free to apply its own law in Hughes so long as it had a legitimate interest in so doing. Wisconsin clearly did have such an interest. All the parties in Hughes were domiciliaries of Wisconsin. The policy underlying both the Wisconsin and Illinois wrongful death statutes is to protect the surviving members of a domiciliary's beneficiaries. 65 Illinois could have no interest in extending its statutory benefit for the protection of the Wisconsin beneficiaries. 66 And IIlinois had no interest in protecting the Wisconsin defendants from a judgment which Illinois would consider excessive, for the defendants had no continuing

58 "[T]he full-faith-and-credit clause, if it means anything, means that the forum state must defer to the law of the only state having an interest in the application of its law and policy; there is no room for an inconsistent 'local public policy,' since it has already been determined that the forum state has no legitimate interest in the matter." Currie, The Constitution and the "Transitory" Cause of Action, 73 HARV. L. REV. 36, 42 (1959). "The policy embodied in the full-faith-and-credit clause is that each state shall give appropriate effect to the public acts, records, and judicial proceedings of sister states, and shall refrain from intruding its own notions and policies into matters which are properly the concern of others." Id. at 270 .

59 Carroll v. Lanza, 349 U.S. 408 (1955); Wells v. Simonds Abrasive Co., 345 U.S. 514 (1953); Pacific Employers Ins. Co. v. Industrial Acc. Comm'n, 306 U.S. 493 (1939); Alaska Packers Ass'n v. Industrial Acc. Comm'n, 294 U.S. 532 (1935).

60294 U.S. 532 (1935).

$61 \mathrm{Id}$. at $547-48$.

62349 U.S. 408 (1955).

63348 U.S. 66 (1954).

64306 U.S. 493 (1939).

65 Both statutes are modeled after Lord Campbell's Act, 9 \& 10 Vict. c. 93 (1846), providing for specific beneficiaries. See IrL. ANN. Stat. ch. 70 (Smith-Hurd 1936); WIS. Stat. $\S 331$ (1949).

66 It must be presumed that a legislature enacts laws for the protection and benefit of its own residents, not those of other states. Cf. Grant v. McAuliffe, 41 Cal. 2d 859, 264 P.2d 944 (1953); Lams v. F. H. Smith Co., 36 Del. 477, 482-83, 178 Atl. 651, 653 (1935). 
contact with Illinois. Only Wisconsin had an interest in this situation and the parties; Illinois had none. 67

Does Hughes then preclude the New York court from applying its own law in Kilberg? If the "legitimate interest" test of Carroll, Watson, and Pacific Employers is utilized, New York should be free to apply its law. But if the "balancing of interests" test of Alaska Packers is called forth, it seems dif-

67 "In a loose and abstract way, to be sure, one may say that the state of injury has an 'interest' in securing compensation whether the injured person dies or not: there is the same need to see to it that the expenses of medical and hospital care, or even of burial, do not fall upon the state or its residents." Currie, The Constitution and the Choice of Law: Governmental Interests and the Judicial Function, 26 U. CHI. L. REV. 9, 27 (1958). Therefore, it may be urged that this interest is protecting local creditors is a sufficient basis to call for the application of the forum's own law. This would be true if the action were one for personal injuries where the damages recovered are general assets of the injured party. See Pacific Employers Ins. Co. v. Industrial Acc. Comm'n, 306 U.S. 493 (1939). But the great majority of wrongful death statutes, patterned after Lord Campbell's Act, provide that damages recovered are for the benefit of designated beneficiaries only; the damages recovered do not become assets of the estate available for the satisfaction of claims of creditors of the deceased. E.g., ILL. REV. STAT. ch. 70 \& 2 (1959): "[T] he amount recovered in every such action shall be for the exclusive benefit of the widow and next of kin of such deceased person. ..." Because Illinois' policy of protecting its creditors is not expressed in its death act, this policy cannot be asserted as a ground upon which to predicate the application of the Illinois statute.

It may be also asserted that Illinois has an interest in promoting highway safety within its borders, and, therefore, that it has an interest in the adjudication of this case involving an accident on Illinois public roads. A death action, however, is not the proper type of action in which to express this interest. A death action is a compensatory one for the benefit of the deceased's dependents, not a punitive one designed to punish and deter reckless and negligent conduct. (The Massachusetts statute, however, does have penal characteristics. MASS. ANN. Laws ch. 229, § 2 (1955). See Notes, 27 B.U.L. Rev. 88 (1947); 29 B.U.L. Rev. 523 (1949).)

Because only Wisconsin had a legitimate interest in the Hughes situation, it is suggested that if the action had been brought in Illinois rather than Wisconsin, the full faith and credit clause would have required application of Wisconsin law to determine the rights of the parties. Cf. Bradford Elec. Light Co. v. Clapper, 286 U.S. 145 (1932), a wrongful death case in which the Supreme Court held that full faith and credit required the state where the fatal injury occurred to defer to the state of employment's purportedly exclusive workmen's compensation act. The employee-decedent was a resident of Vermont, the employer-defendant was a Vermont corporation, and the contract of employment was entered into in Vermont. The decedent was electrocuted in New Hampshire when he was sent across the river which divides Vermont from New Hampshire to repair one of defendant's installations. He left surviving no dependents. Under the workmen's compensation law of Vermont his administrator was entitled only to burial expenses. The New Hampshire law permitted the employee or his representative to elect to sue for damages at common law rather than for compensation. The action was brought by an administrator, a New Hampshire resident, to recover for wrongful death.

After examining Hughes in the light of previous Supreme Court cases, Professor Currie has concluded that the holding was actually founded on the equal protection clause. Wisconsin was, in fact, discriminating between its own citizens by allowing its domiciliaries access to its courts only if the death occurred within the state. See Currie, The Constitution and the "Transitory" Cause of Action, 73 HARv. L. REv. 36, 268 (1959). This interpretation is a persuasive one, especially in view of this statement in Wells v. Simonds Abrasive Co., 345 U.S. 514, 518-19 (1953): "The crucial factor in those two cases [Hughes and United] was that the forum laid an uneven hand on causes of action arising within and without the forum state. Causes of action arising in sister states were discriminated against." 
ficult, if not impossible, to determine which of the two states, Massachusetts or New York, has a greater interest in the Kilberg situation. 68 In any event, the New York court has tended to obscure its interest of protecting its domiciliaries by holding that the issue of damages is a procedural question. 69

This procedural holding may also raise other problems in subsequent cases arising out of the same or a similar fact situation as Kilberg in which the parties in interest are non-residents of New York. Suppose that a domiciliary of Massachusetts is also killed in the same air disaster. His administrator brings suit in New York against Northeast, a Massachusetts corporation doing business in New York.70 It is clear that New York has no interest in giving this Massachusetts domiciliary the benefit of its liberal damage provision.71 Having held that the damage issue is procedural, however, logical consistency now requires the court to apply the forum's damage provision. The court is thus obliged to apply its rule of damages to residents and non-residents alike. To apply the New York damage provision in this case, however, seems senseless. New York's policy of granting maximum awards to its domiciliaries would not be advanced, and the policy of Massachusetts of protecting its defendants from excessive recoveries would be frustrated. The respective interests of New York and Massachusetts simply do not conflict in this case.72

If the court in Kilberg had simply applied its wrongful death act on the ground that its policy of protecting its domiciliaries called for the application of its law, it then could logically decline to apply its law in the Massachusetts decedent's case. But would the refusal to apply the forum's law in this case constitute unconstitutional discrimination in violation of the privileges and immunities clause73-and perhaps the equal protection clause ?74 It cannot be

68 The resolution of such a conflict is within the power of Congress, but it has not seen fit to exercise its authority in this area. See Dodd, The Power of the Supreme Court to Review State Decisions in the Field of Conflict of Laws, 39 HARv. L. Rev. 533, 547, 557 (1926); Currie, The Constitution and the Choice of Law: Governmental Interests and the Judicial Function, 26 U. CrI. L. REv. 9, 17-19 (1958); Hilpert \& Cooley, The Federal Constitution and the Choice of Law, 25 WASH. U.L.Q. 27, 31-35 (1939).

69 The procedural holding will certainly not insulate the case from full faith and credit attack. Although the forum may apply its own law under the guise that it is simply applying its own procedural rule, it must still have a legitimate interest in the case to justify application of its law. See Wells v. Simonds Abrasive Co., 345 U.S. 514 (1953); John Hancock Mut. Life Ins. Co. v. Yates, 299 U.S. 178 (1936).

70 Barnes v. Union Pac. R.R., 139 F. Supp. 198 (D. Idaho 1956), is apparently such a case. Decedent and his beneficiaries were Oregon residents, the fatal injury occurred in Oregon, and the defendant railroad was doing business in the forum, Idaho. Oregon maintained a statutory limit on death damages; Idaho did not. Held, the amount of damages recoverable is determined by the lex loci delicti, Oregon.

71 See note 66 supra.

72 See Currie, Survival of Actions: Adjudication versus Automation in the Conflict of Laws, 10 STAN. L. REv. 205, 225-31 (1958), where the "false conflict" problem is discussed.

73 U.S. Const. art IV, §2. See generally, CORWIN, ThE CONSTITUTION OF THE UNITED STATES OF AMERICA-ANALYSIS AND INIERPRETATION 686-93 (1953); Currie \& Schreter, Unconstitutional Discrimination in the Conflict of Laws: Privileges and Immunities, 69 YALB 
deemed to be unconstitutional discrimination when a court refuses to apply its own law when it has no interest in the case, but applies the law of the state which is interested. "In the pursuit of its altruistic interests, a state must stop short of trenching upon the interests of other states; therefore, the privileges and immunities clause does not require a state to extend the benefits of its laws to nonresidents where the state has no interest in so doing, and where so doing would interfere with the policy of a state having a direct interest in the matter."75 Indeed, the Supreme Court has held that to refuse to apply the law of a state having an interest in the situation, and instead to apply the law of a state having no interest, is to deny due process of law to the litigants 76 and full faith and credit to the interested state's law. 77

It should be pointed out that this conclusion would not be true if the defendant were not a Massachusetts corporation, but a corporation chartered under the laws of New York or a third state doing business in New York. In this situation, Massachusetts would have no interest in the application of its limited damage provision designed to protect its own corporations. Although New York would have no interest in awarding the plaintiff-administrator (representing the deceased and his beneficiaries) maximum damages, there would be no basis for withholding from him the benefit of the forum's extended damage award. The Massachusetts' policy would not be advanced or defeated by applying its law. Therefore, full faith and credit or due process would not compel the New York court to apply Massachusetts' law, while privileges and immunities or equal protection would apparently require the court to extend the benefit of its extended damage provision to the Massachusetts plaintiff. It is suggested, however, that New York is not required by the privileges and immunities clause or equal protection clause to award the

L. J. 1323 (1960). "Every right, privilege or immunity created by any state in behalf of its own citizens shall be equally extended to the citizens of other states if withholding it would hinder free social and economic intercourse between the citizens of the several states as one nation." McGovney, Privileges or Immunities Clause, Fourteenth Amendment, 4 Iowa L. Bull. 219, 219-20 (1918), reprinted in 2 Ass'N of AM. LAW Schools, Selected Essays on CONSTITUTIONAL LAW 402, 403 (1938).

74 The applicability of the equal protection clause depends upon the construction of the phrase "within its jurisdiction."If this phrase is interpreted to mean that the person invoking the clause must be within reach of compulsory process of the state's courts (see Blake v. McClung, 172 U.S. 239, 260-61 (1898)), equal protection would not be applicable in this sitution. But if the phrase is construed to mean that voluntary submission to the jurisdiction of the state's courts brings the party "within its jurisdiction" (see Kentucky Fin. Corp. v. Paramount Auto Exch. Corp., 262 U.S. 544, 550 (1923)), equal protection would then apply. See Currie \& Schreter, Unconstitutional Discrimination in the Conflict of Laws: Equal Protection, 28 U. CHI. L. REv. 1, 5-10 (1960).

75 Currie \& Schreter, Unconstitutional Discrimination in the Conflict of Laws: Privileges and Immunities, 69 YALE L.J. 1323, 1365-66 (1960).

76 Home Ins. Co. v. Dick, 281 U.S. 397 (1930).

77 Bradford Elec. Light Co. v. Clapper, 286 U.S. 145 (1932). 
party more than he would be entitled to under the law of his domicile.78 The basis for such action would not lie in a classification between resident and non-resident-which would clearly be an unreasonable classification under privileges and immunities and equal protection-but a classification based upon the extent to which the party is protected by the laws of the state in which he resides.

Suppose, finally, that the Northeast crash fatally injures a domiciliary of a third state. His administrator brings suit in a New York court, 79 relying on the Kilberg decision. As in the case of the Massachusetts decedent, the court, having held the question of damages to be a procedural one, will be unable to apply any damage law other than that of the forum. If Kilberg had applied the interest rationale rather than the procedural-versus-substantive classification, the court would not be compelled to apply its damage provision. 80 But what law would it then apply-that of the third state or that of Massachusetts? If the statutes of the two states are identical, there is no conflict, and it is unnecessary to make a choice. If the statutes are not identical, they must represent conflicting policies. Upon what basis is the New York court to determine which of the two policies is to prevail? It has been stated that our system of conflict of laws does not produce a rational solution to the question, 81 and that our system of sovereign jurisdictions does not permit a court in one state to weigh the competing interests of two other sovereign states. 82 Three pos-

78 See Currie \& Schreter, Unconstitutional Discrimination in the Conflict of Laws: Equal Protection, 28 U. CH. L. REv. 1, 36-42 (1960).

79 See Howard v. Pulver, 329 Mich. 415, 45 N.W.2d 530 (1951), involving an analogous factual situation.

80 See text supra at notes 71-75. Massachusetts and the third state are now the interested jurisdictions. The application of the forum's law will neither advance nor frustrate its policy. It cannot be deemed unconstitutional discrimination when a court applies the law of an interested state when the forum has no interest in applying its law.

81 See Currie, Survival of Actions: Adjudication versus Automation in the Conflict of Laws, 10 Stan. L. Rev. 204 (1958); Currie, On Displacement of the Law of the Forum, 58 Colum. L. REv. 964 (1958).

82 "[W]here several states have different policies, and also legitimate interests in the application of their policies, a court is in no position to 'weigh' the competing interests, or evaluate their relative merits, and choose between them accordingly. ... I know that courts make law, and that in the process they 'weigh conflicting interests' and draw upon all sorts of 'norms' to inform and justify their action. . . . But assessment of the respective values of the competing legitimate interests of two sovereign states, in order to determine which is to prevail, is a political function of a very high order. This is a function which should not be committed to courts in a democracy. It is a function which the courts cannot perform effectively, for they lack the necessary resources. Not even a very ponderous Brandeis brief could marshall the relevant considerations in choosing, for example, between the interest of the state of employment and that of the state of injury in matters concerning workmen's compensation. This is a job for a legislative committee, and determining the policy to be formulated on the basis of the information assembled is a job for a competent legislative body." Currie, Notes on Methods and Objectives in the Conflict of Laws, 1959 DUkE L.J. 171, 176-77. 
sible solutions may be suggested: (1) apply the law of the forum, 83 (2) utilize an arbitrary choice of law rule, such as lex loci delicti, or (3) dismiss the action under the doctrine of forum non conveniens. 84

The forum non conveniens solution is certainly the most appealing, for it avoids the difficult choice of law issue and does not compel the forum to entertain a suit in which it has no interest in the parties or their respective rights. However, forum non conveniens may not be available for the court's use simply because the jurisdiction may not have adopted it. 85 Should the court then apply its own law or an accepted conflicts doctrine? It seems clear that a state may deprive a party of due process of law by applying the law of any state having no legitimate interest in the situation. ${ }^{86}$ The forum has no interest in this hypothetical case, while two other states do. It would seem that application of the law of either of the two interested states rather than that of the forum would both be more desirable and mandatory under the due process clause. But how is the forum to determine which of the two competing policies should take precedence? In the suggested situation, the lex loci delicti rule leads to a state which has an interest in the situation. 87 But utilization of the rule does not provide a rational choice between the two policies. The interest evaluation which is necessary to make the choice is not performed by a perfunctory conflicts rule. Because no reason appears why the forums should apply a particular foreign law, and because prima facie the forum is entitled to apply its own law, 88 Professor Currie concludes that "here no compelling reason exists for displacing that law by the law of a particular foreign state." 89 He further suggests that application of the lex fori in this situation violates no constitutional provision, for full faith and credit and due process require the

83 Currie, On the Displacement of the Law of the Forum, 58 Colum. L. REv. 964, 1015-17 (1958); Currie, The Verdict of Quiescent Years: Mr. Hill and the Conflict of Laws, $28 \mathrm{U}$. CHI. L. REv. 258, 277-81 (1961). Cf. Ehrenzweig, The Lex Fori-Basic Rule in the Conflict of Laws, 58 Mich. L. REv. 637, 673-75 (1960); Ehrenzweig, The Lex Fori in the Conflict of Laws-Exception or Rule? 32 Rockx Mr. L. Rev. 13 (1959).

84 See Currie, supra note 82 , at $176-80$.

85 Also, the forum may, in fact, be the most convenient one if all the witnesses happen to reside in the state where the action is brought and the defendant is subject to service of process. New York, of course, was instrumental in developing the doctrine. See Bata v. Bata, 304 N.Y. 51, 105 N.E.2d 623 (1952); Collard v. Beach, 81 App. Div. 582, 81 N.Y.S. 619 (1903). For further discussion see Braucher, The Inconvenient Forum, 60 HARv. L. REv. 908 (1947); Dainow, The Inappropriate Forum, 29 ILL. L. REv. 867 (1935).

86 See Home Ins. Co. v. Dick, 281 U.S. 397 (1930); Young v. Masci, 289 U.S. 253 (1933).

87 The defendant is a Massachusetts corporation and that state has an interest in protecting its corporation from excessive recovery. In other cases the lex loci delict may have no interest in the application of its policy as expressed in its law. Cf. Hughes v. Fetter, 341 U.S. 609 (1950); Stoltz v. Burlington Transp. Co., 178 F.2d 514 (10th Cir. 1949).

88 Alaska Packers Ass'n v. Industrial Acc. Comm'n, 294 U.S. 532, 547-48 (1935).

${ }^{89}$ Currie, The Verdict of Quiescent Years: Mr. Hill and the Conflict of Laws, 28 U. CHI. L. REv. 258, 278 (1961). 
forum to defer to the foreign law only if that law is the sole and specific law applicable to the situation. 90

Professor Currie would agree, however, that application of the lex fori is not the most desirable solution to the problem if the disinterested state had some guide for determining which of the two states' statutes is to be applied, i.e., which of the two policies is to take precedence. To choose between the conflicting policies of two states is ultimately a decision which must be viewed as a legislative one. The choice is one appropriate for Congress, 91 not for a court. This is not to say that Congress should enact choice of law rules; it should simply decide which of two policies is to be dominant in a conflicts situation of this type-that which protects the deceased and his beneficiaries by granting extended damages, or that which protects the defendant by limiting the amount of recovery.

$90 \mathrm{Ibid}$. Professor Hill, however, concludes that application of the law of the forum would be unconstitutional. Hill, Governmental Interest and the Conflict of Laws $-A$ Reply to Professor Currie, 27 U. Chr. L. Rev. 463, 478 (1960).

91 See CoOK, The Logical and Legal Bases of the Conflict of Laws 90-107 (1949).

\section{PROBATIONER'S RIGHT TO APPEAL; APPELLANT'S RIGHT TO PROBATION}

Of the 26,808 criminal defendants convicted and sentenced in the United States district courts during the year ending June 30, 1958, 10,903 (41\%) were given suspended sentences and placed on probation. ${ }^{1}$ All of the states have some form of suspended sentence and probation or judicial parole procedure. 2 Despite the widespread use of probation, there has been surprisingly little discussion of its legal aspects. ${ }^{3}$ Perhaps because of this neglect, the "law" of probation has failed to provide uniform solutions to recurring legal problems. This comment will deal with three problem areas created

1 [1958] U.S. Admmistrative OfFice of the Unired States Courts, ANN. ReP. OF THE DIRECTOR 208-10, Table D-4 (1959). Annual reports for the years 1954-1957 show a similar incidence of the use of probation. Roughly 25,000 persons are under the supervision of United States probation officers at present. See id., p. 211, Table E-1.

2 Although the terms probation and parole are sometimes used interchangeably, they denote rather different institutions. For present purposes, the word "probation" will be used to designate extra-mural supervision of defendants convicted of crime, ordered by and subject to the control of the sentencing court. "Parole" is an "administrative act of the executive or an executive agency," and, unlike probation, typically follows a period of incarceration. 4 U.S. DEP'T OF JUSTICE, ATr'y GEN. SURVEY OF RELEASE Procedures 1 (1939).

${ }^{3}$ A recent exception may be found in Note, Legal Aspects of Probation Revocation, 59 Colum. L. Rev. 311 (1959). See GlueCK, Probation aNd Creminal Justice 23-46 (1933). The vast majority of the literature of probation, however, concerns itself with sociological and administrative problems. See, e.g., FEDERAL PROBATION, vols. 1-24 (19371960). 